\title{
DynamicSainT
}

Jilid. IV No. 2., Oktober 2019

\section{POTENSI PENGGUNAAN MOBILE AD-HOC NETWORK (MANET) SEBAGAI ALAT KOMUNIKASI DATA PADA TRANSPORTASI DI INDONESIA}

\author{
Esther Sanda Manapa ${ }^{1}$, Eliyah Acantha M Sampetoding ${ }^{2}$, Godfried Lewakabessy ${ }^{3}$ \\ ${ }^{1}$ Transportasi, Sekolah Pascasarjana, Universitas Hasanuddin, Makassar \\ ${ }^{2}$ Ilmu Komputer, Fakultas MIPA, Institut Pertanian Bogor, Bogor \\ ${ }^{3}$ Teknik Sipil, Politeknik Negeri Ambon, Ambon
}

\begin{abstract}
ABSTRAK
Ad Hoc Network adalah jaringan wireless yang terdiri dari kumpulan node bersifat dinamik yang dapat saling berkomunikasi. Node tidak hanya berfungsi sebagai pengirim dan penerima informasi data tetapi juga berfungsi sebagai jalur jaringan tempat informasi data yang terkirim. Mobile Ad Hoc Network (MANET) adalah kumpulan dari beberapa wireless node yang dapat diatur secara dinamis di lokasi manapun dan tidak terbatas waktu tanpa menggunakan infrastruktur jaringan yang ada. MANET tidak memerlukan pusat administrasi dan infrastruktur kabel. MANET pada mobile host yang terhubung dengan wireless dapat bergerak bebas dan juga berperan sebagai router. Makalah ini memberikan wawasan tentang karakteristik MANET, aplikasi potensi dalam memanfaatkan teknologi MANET sebagai Alat Komunikasi Data Transportasi di Indonesia.
\end{abstract}

Kata Kunci : MANET, Komunikasi Data, Transportasi

\section{PENDAHULUAN}

Perkembangan teknologi pada bidang jaringan nirkabel sedang berkembang dengan cepat. Hal tersebut membuka peluang untuk mengembangkan penelitian pada bidang $A d$ Hoc Network. Komunikasi pada Ad Hoc Network tidak memerlukan infrastruktur karena dilakukan secara langsung antar node [1]. Salah satu Ad Hoc Network yang saat ini sedang rutin diteliti dan dikembangkan adalah Mobile Ad Hoc Network (MANET) [2].

MANET adalah kumpulan dari beberapa wireless node yang dapat diatur secara dinamis di lokasi mana pun dan tidak terbatas waktu tanpa menggunakan infrastruktur jaringan yang ada. MANET tidak perlu memiliki pusat administrasi dan infrastruktur kabel. MANET pada mobile host yang terhubung dengan wireless dapat bergerak bebas dan juga berperan sebagai router [3].

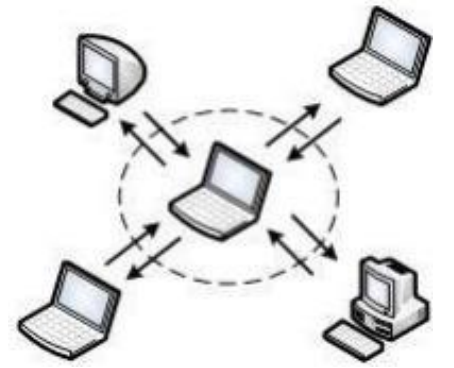

Gambar 1. Model Mobile Ad-hoc Network [4]

Jaringan pada MANET menggunakan komunikasi peer to peer multi hop ketika paket akan ditransmisikan. Ketika node bergerak secara otomatis topologi jaringan akan berubah mengikuti perubahan lokasi node yang bergerak

\section{KARAKTERISTIK MANET}

Media komunikasi Node pada MANET adalah udara dengan menggunakan radio frekuensi $(30 \mathrm{MHz}-5 \mathrm{GHz})$. Node tersebut bisa saja berada di mana saja. Setiap node dilengkapi dengan transmitter dan receiver wireless untuk memancarkan gelombang radio yang disebut dengan 


\section{DynamicSainT}

Jilid. IV No. 2., Oktober 2019

Broadcast Communication [5].

Broadcast Communication dalam jaringan MANET adalah proses penyebaran informasi untuk mengirim pesan dari source node ke semua node pada jaringan. Teknik penyiaran transminis komunikasi pada MANET tergantung dari kekuatan sinyal yang berhubungan dengan lingkungan dan waktu. Selain itu, perpindahan node juga menciptakan topologi komunikasi yang terus berubah secara dinamis [6]. Transmisi wireless bisa menggunakan HSDPA, WiMax, WLAN untuk mendukung Ad Hoc Network.

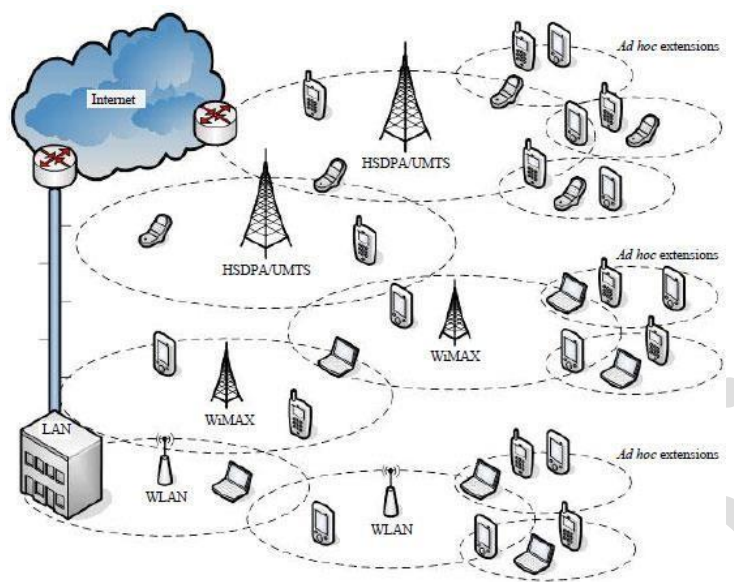

Gambar 2. Integrasi MANET dengan berbagai Jaringan [7]

\section{Karakteristik MANET juga} dijabarkan sebagai berikut [3]:

\section{Topologi Dinamis}

MANET dapat menyediakan infrastruktur jaringan komunikasi data secara dinamis asal node berada dalam transmisi radio. Setiap terminal host dapat membangun komunikasi data asalkan host-computer antar node berada dalam jangkauan. Sifat dinamisnya yaitu perangkat nya dapat berpindah-pindah dimana saja [8].

\section{Otonomi}

Setiap node pada MANET dapat berperan sebagai end-user sekaligus menjadi router penghubung jalur komunikasi [9].

\section{Bandwidth}

Jaringan wireless cenderung memiliki kapasitas yang rendah jika dibandingkan dengan jaringan menggunakan

kabel. Pada wireless juga terdapat keterbatasan area transmisi gelombang yang dipancarkan tergantung kemampuan memancarkan sinyal [9].

\section{Energi}

Semakin besar jarak sinyal atau semakin banyak sinyal yang dipancarkan maka semakin besar energi yang dibutuhkan ketika node membangun jalur komunikasi.

\section{Routing Protocol}

Routing Protocol berfungsi untuk menentukan cara router berkomunikasi satu sama lain, mendistribusikan informasi yang memungkinkan setiap node untuk memilih rute jalur komunikasi pada suatu jaringan. Terdapat berbagai jenis protocol routing pada MANET dan yang saat ini sudah stabil dan sering digunakan dalam pengembangan penelitian adalah AODV, DSDV, OLSR, OLSR, dan DSR [10, 11, 12, 13, 14]. Gambar 3 Berikut adalah jenis Routing Protocols yang digunakan pada Ad Hoc Networks.

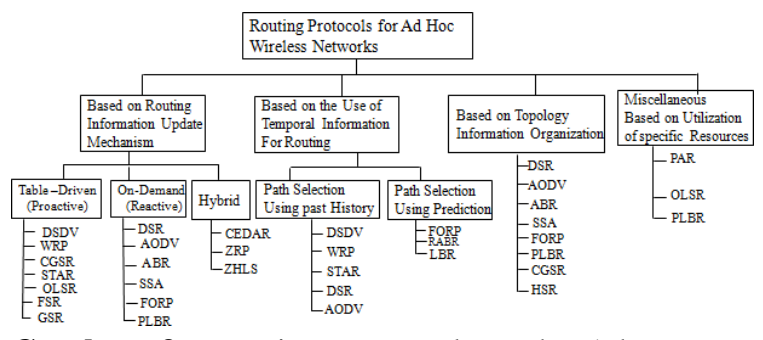

Gambar 3. Routing Protocols pada Ad Hoc Wireless Network [15]

Selain itu, terdapat teknik terbaru komunikasi VANET yakni menggunakan SDN (Software Defined Network) yang berbagai Penelitiannya sudah dimulai sejak tahun 2015 hingga sekarang [16].

\section{POTENSI PENGGUNAAN MANET DI BIDANG TRANSPORTASI}

\subsection{Vehicular Ad Hoc Networks}

Kendaraan yang memiliki pergerakan 


\section{DynamicSainT}

Jilid. IV No. 2., Oktober 2019

cepat dan saling berkomunikasi disebut dengan Vehicular Ad Hoc Networks (VANET) [17] . Teknologi VANET memungkinkan komunikasi antar kendaraan pada lingkup area dalam jarak 100 hingga 500 meter [18].

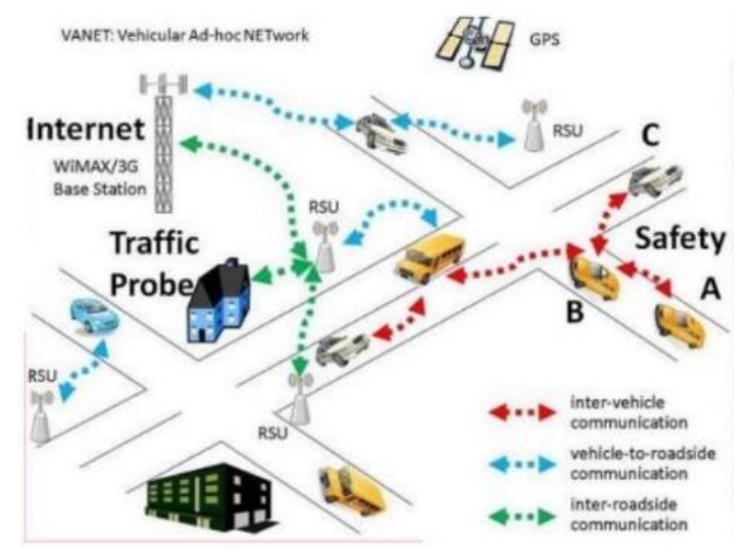

Gambar 4. Gambaran umum arsitektur sistem VANET [19]

VANET akan berperan pada pengembangan teknologi Intelligent Transportation System [20] dalam memberitahukan informasi kejadian dijalan yang akan dilalui misalnya trafik lalu lintas. Hal paling penting pada VANET adalah harus dapat diandalkan.

\subsection{Fasilitas Transportasi}

Fasilitas transportasi yakni Terminal Bus, Statsiun Kereta Api, Bandara dan Pelabuhan. Sebagai contohnya Potensi Penerapan MANET dapat digunakan Terminal Bus dan Pelabuhan yang ingin ditingkatkan kualitas pelayanannya.

Misalnya Terminal Bus Arjosari kota Malang [21], Hadirnya sistem Ad Hoc Network dapat menghubungkan jaringan antara server terminal bus terhadap setiap bus yang akan keluar maupun masuk dari dan kedalam Terminal. Selain itu, misalnya Penggunaan teknologi MANET mampu mendukung Servis Pelayanan pada Pelabuhan Kota Ambon [22] agar data logistik bisa cepat diinformasikan melalui aplikasi Jaringan.

\section{KESIMPULAN}

Makalah Studi Literatur ini memberikan gambaran umum mengenai berbagai karya penelitian yang berkaitan dengan MANET dan potensi penerapan teknologi MANET pada layanan Transportasi. Gambaran umum ini diharapankan mendorong peneliti di Indonesia bidang ad-hoc network dalam mengimplementasi potensi penerapan teknologi MANET sebagai alat komunikasi data bidang transportasi di Indonesia.

\section{DAFTAR PUSTAKA}

1. I. N. Dewi, R. Munadi and L. Vidya Y, "Simulasi dan Analisis Performansi Dari Protokol Routing Berbasis Posisi GPRS dan GyTAR untuk Vehicle Communication Pada Vehicular Ad Hoc Network (VANET)," Tektrika, vol. 1, 2016.

2. Binus University, "Introduction of Mobile Ad Hoc Network Manet," Binus University, 169 2017. [Online].

3. [E. A. Manapa, T. N. Fauzi, T. W. Sagala and T. N. Sukma, "Vanet dan Manet," Student Telkom University, 2812015. [Online]. Available: https://taufiknurfauzi.student.telkomunive r sity.ac.id/vanet-dan-manet/.

4. S. Simamora, "Perancangan Topologi Dinamis Secara Acak Dalam Mobile AdHoc Networks Dengan Pendekatan Pemodelan," SIMETRIS, vol. 6, pp. 119128, 2015.

5. P. Aruna and N. Vetrivelan, "Survey and Comparative Study of Wireless Technologies for Enchanced MANET," International Journal of Applied Engineering Research, vol. 10, pp. $2561725627,2015$.

6. I.-H. M. Mkwawa and D. D. Kouvatsos, "Broadcasting Methods in MANETS: An Overview," in Network Performance Engineering, 2011, pp. 767-783.

7. J. Prakash, R. Kumar and J. Saini, "MANET-internet Integration Architecture," Science Alert, vol. 17, pp. 264-281, 2017. 


\section{DynamicSainT}

Jilid. IV No. 2., Oktober 2019

8. A. Wijayanto, I. Wahidah and R. Munadir, "Simulasi Jaringan MANET (Mobile Ad Hoc Network) Untuk Aplikasi Video Menggunakan Pengkodean MPEG-4," Tugas Akhir Universitas Telkom, 2009.

9. Alamsyah, I. K. E. Purnama, E. Setijadi and M. H. Purnomo, "Analisis Kinerja Protokol Routing AODV, DSR, dan OLSR pada Mobile Ad hoc Network Berdasarkan Parameter Quality of Service," Jurnal Rekayasa Elektrika, vol. 14, pp. 145-151, 2018.

10.N. A. M. Saudi, M. A. Arshad, A. G. Buja, A. F. Fadzil and R. M. Saidi, "Mobile AdHoc Network (MANET) Routing Protocols: A Performance Assessment," Langkawi, 2017.

11.F. S. Pratanda, V. Suryani and Setyorini, "Simulasi dan Analisis Performansi Jaringan MANET Menggunakan Routing Protocol AODV dengan DCCP untuk Menangani Congestion," Universitas Telkom, 2012.

12.E. H. Harahap, "Analisis Performansi Protokol AODV (Ad Hoc On Demand Distance Vector) dan DSR (Dynamic Source Routing) Terhadap Active Attack Pada MANET (Mobile Ad Hoc Network) Ditinjau dari Qos (Quality Of Service)," Tugas Akhir Universitas Telkom, vol. 34, 2014.

13.H. A. Anshori and M. Abdurahman, "Analisa Perbandingan Routing Protocol DYMO dan AODV pada Vehicular Ad hoc Networks," Tugas Akhir Universitas Telkom, 2013.

14.M. Nurusshobah, P. H. Trisnawan and K. Amron, "Analisis Kinerja Protokol Routing Dynamic MANET On-Demand (DYMO) dan Cluster Based Routing Protocol (CBRP) pada Mobile Ad-Hoc Network (MANET)," Jurnal Pengembangan Teknologi Informasi dan Ilmu Komputer, vol. 3, pp. 3563-3572, 2019.

15.Sunil, F. J. Ansari and S. Tanveer, "An Enegy Efficent Secure Zone-Based Routing Protocol for Mobile Ad-Hoc Networks," in An Energy Efficient Secure Zone-Based Routing Protocol for Mobile Ad-Hoc Networks International Conference on Computer Science and Engineering, New Delhi, 2012.
16.E. A. Manapa, S. Wahjuni and S. N. Neyman, "Rancang Bangun Protokol Perutean SDGR+R pada Vehicular ADHOC Network Berbasis Arah," Jurnal Teknologi Informasi dan Ilmu Komputer, 2020.

17.R. N. Hidayah, Indrabayu and I. S. Areni, "Analisis Performansi Protokol Routing Proaktif pada jaringan Mobile Adhoc," JPE-UNHAS, vol. 22, pp. 120-128, 2018.

18.P. D. Pradana, R. M. Negara and F. Dewanta, "Evaluasi Performansi Protokol Routing DSR dan AODV Pada Simulasi Jaringan Vehicular Ad-Hoc Network (VANET) Untuk Keselamatan Transportasi Dengan Studi Kasus Mobil Perkotaan," e-Proceeding of Engineering, vol. 4, pp. 1996-2004, 2017.

19.Gadkari, Y. Mushtak and B. Nitin, "VANET: Routing Protocols, Security Issues and Simulation Tools," IOSR Journal of Computer Engneering (IOSRJCE), vol. 3, pp. 22-23, 2011.

20.S. Baras, I. Saeed, H. A. Tabaza and M. Elhadef, "VANETs-Based Intelligent Transportation Systems: An Overview," in International Conference on Computer Science and its Applications, 2017.

21.D. S. City, A. Muzakki, A. Wicaksono and Rahayu K., "Evaluasi Kinerja Operasional dan Pelayanan Terminal Bus Arjosari di Kota Malang," Naskah Publikasi Universitas Brawijaya, 2018.

22.E. S. Manapa, "Priority Analysis and Strategy Fisheries Transportation Services in Pelabuhan Perikanan Ambon," Torani, vol. 3, pp. 1-9, 2014. 